www.cya.unam.mx/index.php/cya

Contaduría y Administración, 64 (4), Especial Gobierno Corporativo, 2019, 1-27

\title{
The moderating effect of internal audit on the relationship between corporate governance mechanisms and corporate performance among Saudi Arabia listed companies
}

\author{
El efecto moderador de la auditoria interna en la relación entre mecanismos de \\ gobierno corporativo y desempeño corporativo entre las compañías de \\ Arabia Saudita que cotizan en bolsa
}

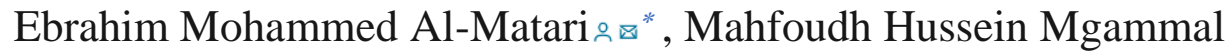 \\ Department of Accounting, College of Business, Jouf University / Kingdom of Saudi Arabia
}

Received September 28, 2018; accepted April 26, 2019

Available online April 30, 2019

\begin{abstract}
This study primarily aimed to assess the internal audit function's ability to detect and self-report fraud. The paper investigated the moderating role of internal audit on the relationship between corporate governance mechanisms and corporate performance (ROA) and the direct effect of corporate governance characteristics and internal audit characteristics on corporate governance of firms listed in the stock market of Saudi Arabia. One hundred and eighty-eight observations obtained from forty-seven Saudi financial firms were used in this study for the years 2014-2017. The study used the FGLS regression to test the variables relationships and to test the moderating effects of internal auditor on the corporate governance characteristics and corporate performance. The obtained empirical results supported a significant positive relationship between non-executive board, audit committee size, audit committee independence and internal audit profession, and corporate performance. Negative significant findings were also observed between the board size, internal audit size and internal audit education, and corporate performance. As for the moderating effects, the results supported a significant moderating role of internal audit size on the size of the board and its relationship with corporate performance.This study extends past studies dedicated to testing the agency theory and resource dependence theory as underpinning theories in examining the relationship between corporate governance and corporate performance. The study is expected to contribute to conceptual and theoretical studies by highlighting issues concerning corporate governance practice in Saudi listed firms. The study focused on the internal audit committee characteristics, corporate governance characteristics and the corporate governance best practices that practitioners can utilized when it comes to the role of internal audit committee.
\end{abstract}

JEL code: M40, M41, M10

Keywords: Corporate governance; Internal audit, Corporate performance; Saudi Arabia stock market

\footnotetext{
${ }^{*}$ Corresponding author.

E-mail address: ibrahim_matri7@yahoo.com (E. Mohammed Al-Matari).

Peer Review under the responsibility of Universidad Nacional Autónoma de México.

http://dx.doi.org/10.22201/fca.24488410e.2020.2316

0186- 1042/@2019 Universidad Nacional Autónoma de México, Facultad de Contaduría y Administración. This is an open access article under the CC BY-NC-SA (https://creativecommons.org/licenses/by-nc-sa/4.0/)
} 


\section{Resumen}

Este estudio primordialmente se enfoca en evaluar la capacidad de la función de auditoría interna para detectar y autoreportar el fraude. El trabajo investigó el papel moderador de la auditoría interna en la relación entre mecanismos de gobierno corporativo y desempeño corporativo (ROA) y el efecto directo de las características del gobierno corporativo y características de la auditoría interna sobre el gobierno corporativo de firmas registradas en el mercado de valores de Arabia Saudita. Ciento ochenta y ocho observaciones obtenidas de cuarenta y siete firmas financieras saudís se usaron en este estudio para los años 2014-2017. El estudio usó la regresión FGLS (mínimos cuadrados generalizados factibles) para probar las relaciones variables y probar los efectos moderadores del auditor interno sobre las características del gobierno corporativo y del desempeño corporativo. Los resultados empíricos resultantes soportaban una importante relación positiva entre consejeros no ejecutivos, tamaño del comité de auditoría, independencia del comité de auditoría y de la profesión de auditoría interna, y el desempeño corporativo. Se observaron también resultados negativos entre el tamaño del consejo, el tamaño de auditoría interna y educación sobre auditoría interna, y desempeño corporativo. En cuanto a los efectos moderadores, los resultados soportaron un importante papel moderador del tamaño de la auditoría sobre el tamaño del consejo y su relación con el desempeño corporativo. Este estudio amplía estudios anteriores dedicados a probar la teoría de la agencia y la teoría de dependencia de los recursos como las teorías que apuntalan el examen de la relación entre gobierno corporativo y desempeño corporativo. Se espera que el estudio contribuya a los estudios conceptuales y teóricos al subrayar temas que conciernen a la práctica del gobierno corporativo en firmas saudís registradas en bolsa. El estudio se centró en las características del comité de auditoría interna, características del gobierno corporativo y las prácticas óptimas de gobierno corporativo que los profesionales pueden utilizar cuando se trata del papel del comité de auditoría interna.

Código JEL: M40, M41, M10

Palabras clave: Gobierno corporativo; Auditoría interna; Desempeño corporativo; Bolsa de Arabia Saudita

\section{Introduction}

In the current dynamic marketplace, effective corporate governance (CG) has been garnering increasing public and regulatory attention, with the important part of CG being internal audit function. This increasing attention goes hand in hand with the public concern regarding the level of fraud that has been rampantly reported among organizations. In this regard, CG comprises of policies, laws and instructions that affect the management and control of the firm. It comprises of a rules framework that ensures the establishment of transparency and fairness on the firm's relationship with its shareholders. The

CG framework is made up of external as well as internal contracts between employees and shareholders and it covers the dissemination of responsibilities, rewards and conditions that assist in steering clear of conflict of interests (Buallay, Hamdan\&Zureigat, 2017). In addition, the concept of CG holds considerable significance owing to the notable financial declines and the economic crises occurring in many money market states and corporations in different parts of the world (East Asia, Latin America and Russia) in the 1990s.

In particular, the U.S. economy has recently undergone financial and accounting declines that brought on the 2008-2009 financial crises around the globe. According to Alotaibi (2015), this holds the major reason for emphasis on the existence of lack of transparency and disclosure of the financial and accounting data of major corporations and economic units that drive the money markets.

Therefore, in the present paper, the gap in literature is addressed by taking on recent cases to explain the relationship between CG mechanisms and corporate performance $(\mathrm{CP})$ of Saudi firms through searching for the answers to the following main research question; does internal audit have a moderating role in the CG mechanisms-CP (return on assets (ROA)) relationship. Accordingly, this study conducts an analysis of several hypothesized potential effects, while examining the direct CG characteristics and internal audit characteristics on CP of Saudi stock market firms. The sample of a firmlevel panel data set was exposed to feasible general least squares (FGLS) statistical analysis.

In 2016, the Saudi Vision 2030 was launched to realize a development vision that involves financial and capital markets and their accessibility from other countries around the globe, enabling considering investments and boosting 
economic growth. The Vision was also aimed to promote continuous stock investment and trading access to stock markets, private firms and state-owned firms in Saudi Arabia (e.g., Aramco). The author found Saudi Arabia to be a good country of choice as it has a ripe commercial environment characterized by a promising degree of competitiveness, almost non-existent taxation, developed judicial system and a robust investment environment (Buallay, 2018). Added to the above, Saudi Arabia is considered to be the dominant country in the Middle Eastern area on the basis of size, with a large-sized market economy (Alsaeed, 2006), contributing 25\% of the total gross domestic product (GDP) of the region (Ministry of Foreign Affairs, Saudi Arabia, 2005). In this relation, the facilitated growth by the GNP had the government direct its resources and focus to the promotion and determination of opportunities to invest in. Added to this, in the Arab region, Saudi Arabia is deemed to the highest income country based on the report by the FTSE Global Markets (20060, with high budget surpluses enabling the country to promote investments of financial reserves for economic growth that leverages both local and foreign firms. It is thus significant to adopt CG practices and to promote and maintain quality reporting.

Also, the Saudi stock market is among those in the developing world that has been consistently reporting high development, particularly in the Middle East and Asia. Its rapid growth in companies and volume has the impetus to propel the country to be the market leader in the Arab region. Nevertheless, the realization of such position requires addressing challenges existing in the market system.

Accordingly, it is necessary to trace back the origin of the Saudi stock market to 1975, where only 14 firms were listed in the stock market. By the 1980s the market had already gone significant changes brought about the oil price increase in 1973. For the management of shareholders records and share certificates, the government established the Saudi Shares Registration Company (SSRC) to oversee the relevant developments in this field from the 1990s to the present time. According to Alajlan (2015), statistics reported by the World Federation of Exchange 2002 Market Capitalization, the Saudi stock market obtained the $9^{\text {th }}$ position among the global emerging markets, with increased developments in 2003.

With regards to governance reforms, Saudi Arabia has been undergoing several of them, beginning with the internal control systems focus, with the standard-setters in the country issuing internal control standards by 2000. Added to this, the Saudi firms are mandated to structure their internal control system on the basis of such standards. Al-Janadi, Rahman and Alazzani (2016)related that Saudi Arabia began issuing CG codes by 2006, with Saudi listed firms mandated to adhere to them in 2010. Soon after, the country became the second country in the Gulf, next to Oman to adopt CG in the public firms. The CG regulations primarily aims to promote standardized guidelines in the form of rules, regulations and best practices among listed firms in Saudi Arabia's Tadawul and to guide investors. Such regulations was adopted to safeguard investors at all levels, specifically minority shareholders and to furnish legal tools to assist them in practicing and safeguarding their rights, so that unjust practices of the majority shareholders can be discerned and reported easily. Saudi Arabia began practicing CG in 1965, with the introduction of the Companies Law of private and public companies. By 2006, the stock exchange market in the country experienced a crash, with the general index tumbling to $25 \%$, after which the shareholders' confidence was largely lost. This precipitated the issuance of rules and regulations by the Capital Market Authority (CMA) to safeguard from future crises. The first code of CG regulation was announced in the country and the entire rules that were voluntary, at first, were made mandatory by the beginning of 2009.

In the present times, the banking and insurance sector has a key role in developing the national economy through the facilitation of financial transactions. There is a competitive environment and globalization business challenges among the Gulf countries that urged banks to restructure themselves and become knowledge-intensive as opposed to traditional bank resource capitalizing units. The objectives of the Gulf countries are to be knowledge-based economies and to minimize the large dependence on export fuel and gas as the major revenue resources via the transformation of rent-seeking economic to knowledge-based ones as evidenced in prior literature (Al-Obaidan, 2008; Buallay, 2018). In relation to this, CG encompasses the processes of board effectiveness and enhanced transparency of disclosures. Such requirements promote 
enhanced quality and quantity of access to information among investors. In other words, effective CG processes help in the development of a capital market that is characterized by dynamism and efficiency and investor's confidence, with higher levels of CG standards adopted among firms.

In addition to the above studies, internal audit effectiveness have a key role in promoting auditee effectiveness and enhanced performance as Dittenhofer (2001) argued and based on his study, maintaining internal audit quality can enhance the procedures and operations that the auditee goes through. This is an indication that internal audit does promote effectiveness of auditee and organizational performance. Similarly, internal audit has a key economic role and internal audit provides more benefit that an external audit in that the former provides timely and accurate information access and determines issues before they are magnified (Xiangdong, 1997). The theory of transaction cost economics demonstrates how internal audit recommendations can enhance the management of public firms (Spraakman, 1997).

The capability of furnishing relevant findings and recommendations can determine audit quality as it is what makes the heart of audit. It is pertinent for internal audit to prove its value to the organization and maintain organizational reputation (Sawyer, 1995). According to Ziegenfus (2000) and GetieandWondim(2007), internal audit needs to conduct a self-evaluation and continuous service improvement.

This study was incentivized by contributing to investors, regulators and corporate managers' knowledge concerning the internal audit function and its value that is related to the fraud detection area. Saudi Arabia was a good choice owing to the fact that it is one of the Gulf countries characterized by globalization business challenges and backed by a competitive environment, where banks are mandated to structure themselves into knowledge-intensive as opposed to traditional units that capitalize bank resources. In the current times, the banking and insurance sectors in the country play a key role in developing the general economy through the facilitation of financial transactions.

Based on the discussion, most prior empirical studies have clearly tackled the CG mechanisms relationship with CP in the Western nations including the United States of America (U.S.), United Kingdom (U.K.), Germany and Australia, with only a few that examined the same in the context of developing markets (e.g., Saudi Arabia). This was also supported and mentioned in related studies by Albassam (2014), Al-Ghamdi and Rhodes (2015), Al-Matari, Al-Swidi, Faudziah, and Al-Matari(2012), Al-Nodel and Hussainey (2010), Alsaeed (2006), Al-Sahafi, Rodrigs and Barnes (2015), Ghabayen (2012), Fallatah and Dickins (2012), Mgammal (2017) and Buallay (2017, 2018),

Hence, this study's distinctive nature is its examination of the direct internal audit mechanism comprising the size and education of internal audit, and internal audit profession, to mitigate the empirical studies gap in both nation contexts. The study is, one of a kind, in examining the moderating role of internal audit on the relationship between CG mechanisms and CP.

As for the remainder of this paper, the sections contain the following contents; the second section address institutional setting discussions and the proposed study hypotheses. This is followed by section three with the collection of data techniques and the study models, and section four with the analysis results. Section five contains the empirical analysis results and the related discussions, while section six provides the study conclusion containing recommendations and prospective avenues that future authors can pursue in line of this research. 


\section{Institutional setting and hypotheses development}

\section{Corporate governance mechanisms and corporate performance}

Prior literature dedicated to the CG-CP relationship was led by Berle and Means (1932), Fama and Jensen (1983), Jensen and Meckling (1976), Shleifer and Vishny (1997) and Smith (1776) and the above authors evidenced the significance of ownership-management separation in enhancing CP and obtaining and maintaining shareholders' confidence.

According to Walsh and Seward (1990), internal governance mechanisms are used by shareholders in ensuring the alignment of their goals with those of management goals. Suffice it to say, internal mechanism are largely dependent on effective board structure, appropriate compensation packages for chief executive officer (CEO), and concentrated ownership for the facilitating of effective oversight (Pissaris, Jeffus\& Gleason 2010).

In the same line of study, Al-Ghamdi and Rhodes (2015) examined family ownership, CG and Saudi-listed companies' performance in their study involving 792 observations for the years 2006 to 2013. Based on the findings of their analysis, ownership has no relationship with CP (ROA). However, in Khamis, Hussein and Elmogy (2015) study, a significant relationship was reported between CP (ROA) and ownership in the context of listed firms in Bahrain. Their study sample constituted 42 firms observations spanning 5 years from 2007 to 2011 . They found institutional ownership to have a negative relationship with company performance (ROA), and a positive relationship with it otherwise (proxied by other than ROA).

Moreover, Fallatah and Dickins (2012) examined CG characteristics and CP relationship in listed firms in Saudi Arabia, with 292 observations for the years 2006 to 2009, with ROA as a CP measure. They reported no relationship between CG and CP (proxied by ROA). In the Bahraini case, Ahmed and Hamdan (2015) examined CG impact on CP, using 42 firms for the years 2007 to 2011, with ROA employed as the performance measure. The findings showed significant correlation between the two variables. In this regard, different findings were reported in the countries around the globe concerning the CG-performance relationship.

Good corporate governance (CG) primarily aims to minimize residual losses (Safari et al., 2015). However, in some prior studies like that of Ahmed and Hamdan's (2015), using 42 firms and observations for the years 2007 to 2011 and return on equity (ROE) as performance measure, the authors reported no significant relationship between CG and ROE as $\mathrm{CP}$.

With regards to Tobin's Q measure to gauge performance, Fallatah and Dickins (2012) examined CG characteristics and CP among Saudi-listed firms, using 292 observations for the years 2006 to 2009. They revealed that CG and Tobin's Q and market value of equity had a positive relationship. Similarly, in the study by Al-Ghamdi and Rhodes

(2015), the authors focused on the relationship between family ownership, CG and performance of Saudi listed firms, using 792 observations for the years 2006 to 2013. Based on their findings, ownership positive related to CP (Tobin's Q). Evidently, a strong relationship has been evidenced in literature between performance and ownership, when the latter's measurement is Tobin's Q. In contrast, using Tobin's Q, Al-Matari, Al-Swidi, Fadzil and Al-Matari (2012) examined the association between internal CG mechanisms and CP (Tobin's Q) in the Saudi context and found no relationship - this rejected the argument of the agency theory.

Other studies dedicated to the Gulf Cooperation Council (GCC) nations include Khamis et al. (2015), a study involving 42 listed Bahraini firms, using data of 5-years (2007-2011). The authors examined the relationship between CG mechanisms and CP and revealed institutional ownership to have a negative association with CP, represented by Tobin's Q, and managerial ownership to have a positive relationship with it. Because of the reported mixed findings in literature, 
Zaman, Arslan, and Siddiqui, (2014) delved into the effects of CG characteristics on CP, using 25 meta-analysis studies results. The study concerned the internal and external governance structures as legal entities and the measurements of the firms' accounting performance. They found external governance, measured by anti-takeover remedies and CP, measured by Tobin's Q to be significantly related to the firm value. The findings motivated the carrying out of the present study and the investigation into the influence of $\mathrm{CG}$ characteristics on $\mathrm{CP}$, and into the internal audit moderating role between the two.

\section{Board of directors and corporate performance}

This section provides a discussion of several board characteristics that play a significant role including size, composition and meeting of board. These variables are pertinent in presenting firm performance in developing nations as noted in prior literature (e.g., Nuryanah\& Islam, 2011; Al-Matari, Al-Swidi\&Fadzil, 2014). Prior studies reported mixed findings on the relationship between the characteristics of board of directors and performance and as yet, no study has examined specific variables (moderators) that affect the CG-CP relationship. Hence, this study is a pioneering one in light of the examination of moderating variables (i.e., internal audit mechanisms) between the relationship of CG and CP.

The preceding paragraphs stressed on the literature gap concerning performance enhancement using CG applications in the listed firms in Saudi Arabia. Therefore, this study is an attempt to fill the literature gap as it investigates the potential drivers of enhancing CG applications among listed firms in Saudi Arabia, and enhancing their CP. This will enable new investors to invest in the country's development. This study examines the characteristics of the board of directors, the audit committee and the risk committee.

\section{Board size and corporate performance}

Board size is an indicator of the board quality and the variable has been garnering attention among researchers, particularly when it comes to its influence on the board's oversight strength. In this regard, the belief is such that the larger the board, the higher its capability of monitoring top management (Abdullah, 2004). The size of the board is described as the number of directors positioned within it and it is viewed to form the core of CG mechanisms, via which monitoring top management is possible for the shareholders (John \&Senbet, 1998). In Buallay's (2018) study, the size of the committee relates to capital employed efficiency(CEE) and on this basis, it can be stated that audit committee size (3-7 members) has a positive relationship with CEE, indicating that the efficiency of GCC banks are brought about by physical and financial CEE as opposed to intangible assets. It is argued that a small-sized board is more capable of creating higher CEE and optimum decision-making compared to a large one. Small-sized audit committees are capable of directing and making informed decisions on using assets, while bigger ones may lead to less performance when it comes to tangible assets. Added to this, in their examination of the CG variables and financial performance relationship among Saudi banks, Al-Sahafi et al. (2015) showed that the size of the board affected the financial performance of firms.

Other studies in this context (United Arab Emirates (UAE) and Saudi Arabia) also supported a negative insignificant relationship between board of directors and firm performance (Aljifri\& Mustafa, 2007; Al-Matari et al., 2012). Owing to the reported mixed findings, a call for more examination is justified. Simlarly, Al-Malkawi (2018) and Fanta et al. (2013) indicated significant negative coefficients when it comes to board of directors (BOD), confirming the argument that large-sized boards may lead to issues regarding free-riders, decisions that are time-consuming and increasing agency costs. In this regard, majority of authors supported a negative relationship between board of directors and corporate performance and these include Mersni and Othman (2016), Yermack (1996), and Lee and Chen (2011). Based on the above discussion, a negative relationship is proposed by this study between the two variables;

H1: Board size has a negative relationship with corporate performance. 


\section{Non-executive board members and corporate performance}

The board characteristics are also depicted by the non-executive board members positioned in the board. According to Uadiale (2012), the board composition refers to the independent non-executive directors in the board in relation to the total directors numbers. Meanwhile, an Anglo-American style unitary BOD consists generally of directors (executive and nonexecutive) that is accountable to the shareholders for both voluntary compliance and disclosure regime. With regards to the board committees, the entire GCC region codes mandate the establishment of audit committee and its composition of mostly independent non-executive directors. Such committee holds the responsibility of and duties that are enumerated in the codes. Among the GCC countries, Bahrain and Oman have established the highest standards in light of remuneration disclosure. Bahrain is the sole GCC country that calls for the approval of shareholders when it comes to remuneration matters and this is aligned with the international standards (Abdallah \& Ismail, 2017).

The agency theory argues that mechanisms used to oversee management primarily safeguard the shareholders' interests from the former selfish actions. Therefore, the external directors number on the board has a positive influence on the business performance as argued by Fama and Jensen (1983), Jensen and Meckling (1976) and Shleifer and Vishny (1997).

Compared to the agency theory, the resource dependence theory argues that external sources offer as a general channel to the firm for performance improvement. With the independent members of the board, there is deeper understanding of the complex environments and there is in-depth knowledge and varying experiences from different sources for performance improvement (Pfeffer, 1972). Both the agency theory and the resource dependence theory posit the positive relationship between board independence and corporate performance. Generally speaking, majority of studies in literature have supported this positive impact (board composition impact on performance) in both country groups (developed and developing) (Al-Sahafi et al., 2015; Bhattrai, 2017; Bace, 2017). On the basis of the theoretical basis and the findings in literature, this study proposes the following hypothesis for testing;

H2: Non-executive board members have a positive relationship with corporate performance.

\section{Audit committee size and corporate performance}

The size of the audit committee (ACC) is also one of the ACC characteristics that have been extensively examined, reflected by the audit committee members in the firm (Nuryanah\& Islam, 2011). The agency theory posits that the managementshareholders conflict often leads to the self-serving interests' fulfillment of opportunistic management, and to the breach of interests of shareholders (Jensen \&Meckling, 1976). Meanwhile, the resource dependence theory argues that a large-sized audit committee is more effective for corporate performance enhancement (Pearce \& Zahra, 1992; Pfeffer, 1987).

In relation to the above, corporate governance has succeeded in transforming the marketplace for the accounting and auditing profession. In the past years, audit committees have been scrutinized for its role as a CG tool used to increase the monitoring of management and in promoting independence among auditors (Hamdan\&Mushtaha, 2011). In fact, the size of the audit committee was evidenced to affect earnings quality, in a way that the bigger the audit committee, the higher will be its effectiveness to monitor management, with diverse knowledge and expertise held by the members within (Hamdan, Sarea\&Reyad, 2013).

In a related study, brought forward a CGI of 27 IBs involving five GCC countries based on their CG internal mechanisms (i.e., board structures, risk management, transparency and disclosure and audit committee, Sharia board and investment account holders) (Srairi, 2015). Data for the years 2008-2011, was ran through content analysis, and the author found that IBs adhered with some of the CGI attributes (54\%), with UAE positioned among the first few countries that complied. The paper indicated an IBS, increased compliance levels and FP relationship. In relation to this study is one by 
Al-Moataz and Hussainey (2012), where the determinants of CG disclosures in Saudi Arabia were examined to determine if there is a relationship between CG mechanisms and the level of information disclosure in terms of the CG practices numbering 9 . The findings showed that audit committee size, board independence, liquidity, profitability and gearing are the top primary determinants of CG disclosure among the firms. This was also supported in the context of Saudi banks by Al-Sahafi et al. (2015) who focused on the CG-Financial performance relationship in a 4-year span (2009-2012). The findings indicated that audit committee size insignificantly related to the banks' financial performance.

Thus, the investigation of the audit committee size-corporate performance relationship and the positive direction of the relationship have been supported in the developed nations (e.g., in Reddy et al., 2010; Al-Matari et al., 2012; Bhattrai, 2017; Al-Sagr, Belkhaoui\&Aldosari, 2018). Based on the above prior studies' findings, this study proposes that;

H3: Audit committee size is positive related with corporate performance.

\section{Audit committee independence and corporate performance}

The independence of the audit committee is another major characteristics of audit committee, with the mandate being that it should contain at least three members, with $2 / 3 \mathrm{rd}$ to be non-executive independent directors. The audit committee independence is a main characteristic that influences the committee's ability to manage financial statements (Baxter \& Cotter, 2009). In fact, audit committee independence is related with the measure of earnings quality and to financial reporting, auditing and CG. In this regard, independent directors should play a role in improving processes that the board members carry out to the level of employing expert and knowledgeable specialists to maintain and help in promoting alliances and acquisitions, for the moral sustenance of the market (Kantudu\&Samaila, 2015).

Moreover, other authors like Al-Sahafi et al. (2015) investigated the linkage between CG variables and financial performance among banks in Saudi Arabia in a 4-year span and revealed that audit committee independence had no significant linkage to the Saudi banks' financial performance. Along with the above studies is a recent study by Buallay (2018) that showed a positive influence of audit committee independence on HCE, RCE, SCE and CEE at 5\% level of significance, indicating that the independence and meetings of the GCC banks audit committee are sufficient to facilitate the full potential of the banks' intangible assets. It also indicates that the audit committee independence influence on intellectual capital (IC), with majority independent GCC banks audit committee members boosting IC through human capital efficiency (HCE), structural capital efficiency (SCE) and relational capital efficiency (RCE). Meanwhile, CEE refers to a tangible element and the GCC banks were evidenced to be more capable of creating value with the help of intangible rather than tangible assets. This is consistent with studies that revealed the inclination of developed firms towards value creation using intangible assets as opposed tangible ones, including those of Celenza and Rossi (2014), Inkinen (2015), Sultana, Singh, and Van der Zahn (2015). Based on the preceding discussion of prior findings, this study proposes that; H4: Audit committee independence has a positive relationship with corporate performance.

\section{Risk committee size and corporate performance}

Following the global financial crisis, financial services corporations primarily concentrated on establishing specific risk committee size (RCs) to deal with risk-related issues and in majority of them, the risk responsibility oversight is held by the AC. This is because members of the AC possess financial expertise to address the process of risk management (Al-Hadi, Hasan \& Habib, 2016). Nevertheless, because of the complex nature of the risks that modern organizations face and the considerable responsibility of $\mathrm{AC}$ in the process of financial reporting, the AC may lack enough time, the right skills and support for the assessment of the overall risks faced by the firm (Field, Lowry \&Mkrtchyan, 2013). Separate RCs are quite discernible in the financial sector because of the sectors' higher expectations of risks from the credit, market, trading, 
adequacy of capital, regulations and compliance (Andres \&Vallelado, 2008). The RCs determinants and consequences have been largely understudied. In fact, Subramaniam, McManus and Zhang (2009) study is the only one that mentioned RCs tendency to be established in companies having independent board chairman and large-sized boards, Evidently, RCs are beneficial to firms in that they enhance the oversight responsibility of the board in terms of risk management and in terms of the expectation and response to events and hard-to-discern trends. Also, distinct RCs have more time and effort to provide for the integration and management of different risks faced by the organizations (Brown et al., 2009).

Risk management has been in the limelight, particularly following the introduction of the CG Acts including the ones in the U.S., which are the new Basel Capital Accord, the Sarbanes Oxley Act, and in Europe, which are the European Sarbanes Oxley (8th company Law Directive, E-SOX) and the European Union financial services Action Plan (FSAP), such as the MiFID (financial services directive markets, other acts and regulations), and in Japan, which is the Japanese Sarbanes Oxley (Financial Instruments and Exchange Law, J-SOX).

Studies empirically examining CG internal factors and CP did not turn their attention to risk committeeperformance relationship. In the present study, the following hypothesis is proposed for testing;

$\mathrm{H} 5$ : There is a positive relationship between risk committee size and corporate performance.

\section{Risk committee independence and corporate performance}

The independence of risk committee (RC) of the board of directors holds the responsibility of the formulation of risk management policies and overseeing their implementation. The risk committee provides the board assistance in their oversight role, particularly the firm's risk-taking activities and it ensures that the firm adheres to the policies and framework of risk management (Ramly\&Nordin, 2018). Such committees are important for safeguarding the stakeholders' interests from unexpected risk exposure (Srinivas, Goradia, Therattil, Dillon, 2015). In the Malaysian context, it is mandatory to have an independent RC in financial institutions and this includes IBs.

In relation to the above, there are three significant bank risk governance attributes and they are; a dedicated RC board-level, RC comprising of majority of independent directors and Chief Risk Officer appointment as the board's executive member (Mongiardino\& Plath, 2010). It is expected that RC establishment reflects a robust risk management and ultimately an optimum CG. Regardless of this fact, akin to board independence, the level to which RC effectively oversees risk management hinges largely on their independence from the executive management team.

On the basis of empirical findings, Ellul and Yeramili (2011) revealed that a significant and independent risk management minimizes risk-taking activities among 74 large-sized U.S. banks. Also, based on prior findings that focused on CG and CP, the risk committee independence factor is largely overlooked and as such, this study proposes the following hypothesis for testing;

H6: There is a positive relationship between risk committee independence and corporate performance.

\section{Internal audit mechanisms and corporate performance}

There is greater contribution of internal audit effectiveness one each auditee effectiveness and on the organization as a whole entity (Dittenhofer, 2001). Maintaining internal audit quality, will lead to improved auditee procedures and operations, and ultimately auditee's and the organization's effectiveness (Dittenhofer, 2001).

Meanwhile, in Xiangdong's (1997) study, the author used agency theory to explain the internal audit role in the economy and its advantage over external audit in accessing timely information and in pinpointing issues at the onset. Also, the theory of transaction cost economics was adopted by Spraakman (1997) to illustrate the way audit recommendations are significant to managing public organizations that are government-owned. 
Moreover, the internal audit quality displayed by the internal audit's ability to offer authentic findings and suggest recommendations is the heart of the committee's effectiveness. Stated clearly, internal audit quality needs to fulfill its role in providing value to the organization and in supporting its reputation (Sawyer, 1995). As such, it has to evaluate its performance for continuous improvement of services offered (Ziegenfus, 2000).

Furthermore, the internal audit quality is clear from its ability to provide accurate findings and list out recommendations, and it is one of the primary factors that direct audit effectiveness. In the IIA standards (1999b), it is mandated that auditors plan and perform tasks to be able to reach useful audit findings and recommend enhancements. It is the internal audit's ability of planning, performing and communicating audit results (proxy of audit quality). Hence, audit quality can be described as extensive staff expertise function, the service scope coupled with effective planning, performing and relaying of internal audit outcome (Mihret, Yismaw, 2007). Therefore, the present study conducted an evaluation of the audit quality determinants by obtaining the answers from the study sample (director of banks and insurance firms) concerning their experience using a survey questionnaire.

Additionally, in the organization's CG structure, internal audit is an important component as evidenced by the role of the internal auditor established by the Institute of Internal Auditor's (IIA) Practice Advisory (2130-1) in terms of ethical practices in the organizational culture. It lays emphasis on the proactive role of internal auditors in facilitating the said culture and in determining assets misappropriation (the institute of internal auditors (IIA).

Although the focus on internal audit has experienced a significant increase, there is still lack of studies on the function's importance. In this line of study, Gramling, Maletta, Schneider and Church (2004) reviewed literature concerning the internal audit role in $\mathrm{CG}$ and reported that most of the studies of this caliber were linked to the external auditors' perceptions and to whether the external auditor employs the work of the internal auditor (Coram, Ferguson, \&Moroney, 2008).

Finally, internal audit functionality maintenance as opposed to outsourcing practices has been evidenced to provide more effectiveness (Coram et al., 2008), and thus, in this study, the internal audit function role in CP is investigated.

\section{Internal audit size and corporate performance}

Moving on to the internal audit size, it is deemed to be a fundamental driver of IA department effectiveness. Emphasis can be found in IIA (IIA, 2017) on the chief audit executive (CAE) responsibility of making sure that the IAF appropriated resources are enough and appropriate. In regards to this, the IA department resources that is ample enough to oversee the business day-to-day activities and the specific transactions, providing a leeway for the detection and prevention of management's self-serving actions (Prawitt, Smith, Wood, 2009). Empirical evidence shows a relationship between IA size, competency and financial reporting (FRQ) (represented by abnormal accruals) (Prawitt et al., 2009). Similar to the above findings, a positive relationship was reported between the features of IA (size and competency), and audit financial statements by Zain, Subramaniam and Stewart (2006). Thus, it can be stated that an under-resources IAF will not be capable of realizing effective efforts and this will ultimately lead to financial information breach (Al-Shetwi, Ramadili, Chowdury, \&Sori, 2011) and to ineffective CG. Thus, this study proposes the following for testing;

H7: Internal audit size has a positive relationship with corporate performance.

\section{Internal audit education and corporate performance}

On the basis of IIA (2017), the sufficient number of IAs and its competence has been stressed. The competence issue among IA staff has been focused on by majority of scholars. According to Abbott et al. (2016), the effect of FRQ is greater in the face of highly competent IA. Similarly, An effective IA provides better insight into the issues that surround management 
bias when it comes to financial reporting and discussion of how to determine bias. Studies of this caliber (e.g., Zain et al., 2006) evidenced a significant relationship between IA features (size and staff expertise) and FRQ in the positive direction. Also, Chris et al. (2015) argued that the rotation in IAs lead to decreased FRQ, indicating a higher tendency for fraud to enter financial reporting (Alzeban, 2018).

However, ineffective IAF in operations may stem from lack of resources (Endaya\&Hanefah, 2006; Zain et al., 2006), which means expert accounting and auditing staff required to ensure the quality of financial reporting (Lee \& Park, 2016). In Saudi Arabia, internal auditors were introduced to IFRS for the first time, and made mandatory in 2012, and as such, it can be argued that the businesses are still unfamiliar with the rules and that education and training is still needed within IFRS environments (Alzeban, 2018), and thus, this study proposes that;

H8: There is a positive relationship between internal audit education and corporate performance.

\section{Internal audit professional certification and corporate performance}

Issues have been noted in ERM as exemplified by the role of internal auditors in its processes. Based on the internal audit professional standards, risk-based approach is adopted in that internal audit function has a significant relation with the risk management process of the business, influencing the internal auditors' professional roles (IASB, 2004; Committee, 2014). Despite the inclination of internal auditors in ERM, there is still lack of consensus as to the internal audit function in the processes, where the internal audit in Research Opportunities in Internal Auditing 2003 (IIARF, 2003) has urged the examination of the roles and functions of internal auditors in ER. The entity along with the Institute of Internal Auditors (2004) has laid down guidelines as to the roles of internal auditors. Studies related to the topic like Beasley et al. (2005a) and Gramling and Myers (2006) examined the role of internal audit in ERM at the micro-level, focusing specifically on the internal audit's ERM related role (Beasley \&Hermanson, 2006). This urged the present work to investigate the influence of internal audit professional certification on corporate performance and to test the following hypothesis;

H9: Internal audit professional certification has a positive relationship with corporate performance.

\section{The moderating effect of internal audit mechanisms on board size and corporate performance}

Internal audit is invaluable for implementing goals and strategiesthat are directed towards realizing the main aims (Ljubisavljevic \& Jovanovic, 2011). In addition, internal audit was primarily introduced toassist in bringing about management and audit committee responsibilities(Hutchinson \& Zain, 2009). Along a similar line of argument, internal auditprovides a true picture of the reliability and integrity of financial andoperational report, within which information is collected from various units ofthe organization. Such information can be useful for management's effective decision-making process.Moreover, successful internal audit task achievement may only bepossible through the independence of the auditor from management, to ensurethat management does not have a say in the information, analysis, and outcomeof the conducted audit. In this way, the internal audit report can be relayedto management in its authentic and accurate form and content to be used forsuccessfully achieving the aims and objectives of the entity (Ljubisavljevic \& Jovanovic, 2011).

It has also been argued that the function of internal audit can effectively run the audit committee because the auditing goals are consistent with those of the financial reporting monitoring of internal audit (Goodwin \& Yeo, 2001). Stated with clarity, the creation of audit function is supported by the governance reports (NYSE, 2002), with prior literature on the subject describing audit function as a tool to enhance internal a government processes (e.g., Goodwin, 2003). The size of the internal audit is the first IAC factor that improves the performance of the company and is measured by the number of internal auditors that are members of the committee. 
The audit committee size has a role in its performance based on various theories. For instance, Jensen (1993) revealed similar findings with Lipton and Lorsch's (1992) findings the prior year, where they both contended that the suitable number of board members is seven-eight. In this regard, eight to fewer members lead to intensified concentration, participation and discussions. Along a similar line of argument, Shaver (2005) related that large board sizes are faced with diffused responsibilities that lead to loafing and groups' fractionalization, as a result of which there will be lack of commitment to change strategy.

Based on the resource dependence theory, the bigger the board size, the more optimum the $\mathrm{CP}$ will be as bigger board could mean higher skills, knowledge and expertise of its members. Also, bigger boards have been argued by Ghazal (2010) to be more able to offer diversity when it comes to acquisition of resources and minimization of risks in the market surroundings.

Moving on to the next IAC factor, which is internal audit education, current internal auditors have to be qualified to be able to maneuver in the current business environment and they have to possess knowledge on business, systems development and other related topics and current trends. They have to know what is workable in the market, the strengths and weaknesses, the systems codes and the procedures to employ (Hala, 2003; Clikeman, 2003). For the chief audit executive, one that is professional should be employed in order to improve the quality of audit. The head should have the right qualifications and certifications (i.e., Certified Government Auditing Professional (CGAP), Certified Financial Services Auditor (CFSA), Certified Internal Auditor (CIA), Certification in Control Self-Assessment (CCSA), and Certification in Risk Management Assurance (CRMA)). Along with the certifications are invaluable feedback of mistakes that are regularly provided. A certified auditor has to have the capability of reaching decisions that are informed, timely and autonomous, together with a qualified chief executive performance can be enhanced (Eighme\&Cashell, 2002).

In this context, firms experiencing good performance are more capable of outsourcing for directors, with prestige being provided by the director's title and job position (D'Aveni, 1990). Directors who are highly qualified are able to oversee management and contribute to the decision making strategies of the firm (Hillman \& Dalziel, 2003) and they are capable of influencing external providers of resources (e.g., financial institutions) to invest in the firm and to market its value to potential investments. On this basis, the study considers the qualification of the chief audit executive to be a significant variable worthy of examination.

Moving on to still another factor of IAC, which is internal auditor professionalism, it has been reported to enhance the quality of internal audit. In relation to this, a highly qualified audit committee member is more capable of addressing issues in the department and as such, this variable is considered in the present study. The agency theory and the resource dependence theory contend that qualified individuals can contribute to the CP enhancement as they are more adept at handling operations and providing high work quality.

It should be noted that studies that examined the internal audit qualification-CP relationship in both nation groups (developed and developing) are still scarce, most especially in the developing nations. The few existing studies include Hutchinson and Zain (2009), who's study concerned the internal audit experience and qualification and their effects on CP (ROA), in the face of growth opportunities and audit committee independence in the Malaysian firms. The authors selected the sample on the basis of the employed questionnaire survey and annual report of 60 firms listed in Bursa Malaysia in a span of a year (2003). Multiple aggression analysis was conducted to analyze data and the relationship between internal audit and $\mathrm{CP}$, after which a significant relationship was supported between internal audit quality qualification and $\mathrm{CP}$.

In Prawitt et al.'s (2009) study, focus was placed on the internal audit quality and earnings management relationship, with the former represented by experience and qualification. Data was gathered to estimate abnormal accrual models for firm-year observations from 218 firms numbering 528, in a 6-year span (2000-2005). The authors made use of least squares regression (OLS) regression to test the variables' relationships and found a significant internal audit 
qualification-earnings management relationship. On the whole, future works in this topic are urged to examine the relationship between internal audit experience and CP as recommended by authors including Al-Matari et al. (2012). This study therefore examines the internal audit qualification-CP relationship by testing the following hypotheses;

H10: There is a moderating effect of internal audit size on the relationship between board size and corporate performance.

H11: There is a moderating effect of internal audit education on the relationship between board size and corporate performance.

H12: There is a moderating effect of internal audit professional certification on the relationship between board size and corporate performance.

\section{Control variables}

Some variables like firm size, leverage, industry and year were considered in literature as control variables - this has been evident in studies by Garcia-Meca and Sanchez-Ballesta (2011) and Al-Matari et al. (2014). Added to this, the above studies indicated that firm size, debt, industry and years influence CP. Hence, this study views the size of the firm, the firm leverage and the bank sector (control variables).

This study follows prior studies regarding firm size as control variable; specifically, firm size and growth were found to be the top determinants of the board size and structure by Patro, Lehn and Zhao (2003). They supported the significant relationship between firm size and board size, and the negative relationship of firm size and growth opportunities. Similarly, the LNSA was utilized by Haniff and Huduib (2006) to measure size - the same measurement was used by Peng, $\mathrm{Li}, \mathrm{Xie}$ and $\mathrm{Su}$ (2010).

Prior empirical findings considered leverage as a control variable when they examined corporate governancefinancial performance relationships (e.g., Al-Matari et al., 2014; Wahla et al., 2012). Based on the studies, debt has a significant effect on the financial performance of the firm, with firm leverage calculated by dividing total liabilities by total assets (Alsaeed, 2006). On the other hand, Jensen (1993) found debt to have a negative relationship with the firm's financial performance and this was attributed to the failure or cost of agency debt by fees. In this study, leverage is calculated by dividing total liabilities by total assets.

The banking sector has a major role in disseminating funds among industries, promoting growth in the economy and in stabilizing the financial health of the country (Shah \& Jan, 2014). It thus goes without saying that an effective banking sector is sufficient to absorb the major financial crisis adverse effects and can be a platform upon which the country's economic system can be supported (Aburime, 2009). The banking sector is represented by a dummy variable (1) if it is a bank, and 0 otherwise.

\section{Data collection and models}

\section{Data collection}

The study data about top management and CP was obtained from the annual reports of Saudi listed firms trading in the stock market. In particular, the data about CP (ROA) was gathered from Data Stream. The sample consisted of 188 financial firms for the years 2014 to 2017, excluding one firm that had no accessible data. Additionally, internal audit data was gathered through questionnaire distributed to the directors of the banks and insurance firms. Lastly, some data was directly collected from the website of the firms. 


\section{Model specification}

The model findings obtained through FGLS method are presented in Table 4. The model contains the entire variables for CG used to explain the linear relationship between internal audit CG mechanisms and CP of Saudi listed firms.

Model 1:ROA $=\beta 0+\beta 1$ BoardSIZE $+\beta 2$ BoardNONEX $+\beta 3$ AUDITCS $+\beta 4$ AUDITCI $+\beta 5$ RISKCS + $\beta 6$

RISKCI + $\beta 7$ InterSIZE $+\beta 8$ InterEDU $+\beta 9$ InterPROF + $\beta 10$ BankSECTOR + $\beta 11$ FIMSI + $\beta 12$ LEVGE+ $\varepsilon i$

Moreover, this study made examined the moderating effects of internal audit on the relationship between CG mechanisms and CP by using the cross-sectional time series FGLS regression.

Model 2: ROA $=\beta 0+\beta 1$ BoardSIZE $+\beta 2$ BoardNONEX $+\beta 3$ AUDITCS $+\beta 4$ AUDITCI $+\beta 5$ RISKCS + $\beta 6$

RISKCI $+\beta 7$ InterSIZE $+\beta 8$ InterEDU $+\beta 9$ InterPROF $+\beta 10$ BankSECTOR $+\beta 11$ FIMSI $+\beta 12$ LEVGE $+\beta 13$

BoardSIZE_InterSIZE+ $\beta 14$ BoardSIZE_InterEDU+ $\beta 15$ BoardSIZE_InterPROFei

\section{Measurement of the variables}

Under this section, the study measures the dependent, independent and control variables. Dependent variable is ROA and board size, board non-executive, audit committee size, audit committee independence, risk committee size, risk committee independence, internal audit size, internal audit education and internal audit professional certificate as independent variables. Moreover, firm size, leverage and bank sector tested as control variables. For more information, refer to table 1.

Table 1

Contains a summarized version of the study variables measurements

\begin{tabular}{|c|c|c|}
\hline \multirow{2}{*}{ Dependent Variable } & Abbreviation & Operationalization \\
\hline & & \\
\hline Return On Assets ratio & $\mathrm{ROA}$ & ROA is calculated as earnings before tax over total company assets. \\
\hline \multicolumn{3}{|l|}{ Experimental Variables } \\
\hline Board Size (number) & BoardSIZE & $\begin{array}{l}\text { Board size is operationalized as the total number of directors } \\
\text { positioned in the BOD. }\end{array}$ \\
\hline Board non-executive (\%) & BoardNONEX & $\begin{array}{l}\text { Board non-executive is calculated by the number of independent non- } \\
\text { executive directors seated at the board of directors in relation to the } \\
\text { total directors. }\end{array}$ \\
\hline $\begin{array}{l}\text { Audit Committee Size } \\
\text { (number) }\end{array}$ & AUDITCS & $\begin{array}{l}\text { The size of the audit committee is measured by the number of } \\
\text { committee members in the committee. }\end{array}$ \\
\hline $\begin{array}{l}\text { Audit Committee } \\
\text { Independence }(\%)\end{array}$ & AUDITCI & $\begin{array}{l}\text { Audit committee independence is operationalized as the number of } \\
\text { non-executive members on the audit committee in relation to the audit } \\
\text { committee size. }\end{array}$ \\
\hline $\begin{array}{l}\text { Risk Committee Size } \\
\text { (number) }\end{array}$ & RISKCS & $\begin{array}{l}\text { Risk committee size is represented by the number of members } \\
\text { positioned in the risk committee. }\end{array}$ \\
\hline $\begin{array}{l}\text { Risk Committee } \\
\text { Independence }(\%)\end{array}$ & RISKCI & $\begin{array}{l}\text { The risk committee independence is operationalized as the number of } \\
\text { non-executive members on the risk committee. }\end{array}$ \\
\hline Internal audit size (number) & InterSIZE & $\begin{array}{l}\text { The size of internal audit is measured by the total number of internal } \\
\text { audit that serves on the internal audit board. }\end{array}$ \\
\hline $\begin{array}{l}\text { Internal audit education } \\
\text { (number) }\end{array}$ & InterEDU & $\begin{array}{l}\text { The internal audit education is operationalized as the number of } \\
\text { internal audit holding Master's degree or PhD. }\end{array}$ \\
\hline $\begin{array}{l}\text { Internal audit professional } \\
\text { certificate(number) } \\
\text { Control Variables }\end{array}$ & InterPROF & $\begin{array}{l}\text { The internal audit professional certificate is operationalized as the } \\
\text { number of internal audit that holds professional certificates. }\end{array}$ \\
\hline Firm size & FIMSI & The firm size is measured by the total assets of the firm. \\
\hline Leverage & LEVGE & Leverage is operationalized as the total debts divided by total assets. \\
\hline Bank Sector & BankSECTOR & $\begin{array}{l}\text { Bank sector is represented by a dummy variable (1) if the firm is a } \\
\text { bank, and } 0 \text { otherwise. }\end{array}$ \\
\hline
\end{tabular}




\section{Sample distribution}

Panel dataset from 47 (188 observations) financial listed firms in Saudi Tadawul was used for a four-year span (2014-2017). The sample frame structure was confined to financial firms as non-financial ones are governed by specific laws that may influence the study variables relationships. The sample frame was formed according to the accessible information of the firms and those who are inclined to responding to the questionnaire survey.

\section{Results}

\section{Descriptive statistics}

Table 2 reveals an average of ROA 0.013 per cent this indicates that ROA tends to be high on the average. The findings imply that the medium BoardSIZE and BoardNONEX of the sample companies is 8.840 and 0.464 per cent, with a maximum of 12.000 and 0.667 per cent and a minimum of 5.000 and 0.000 per cent respectively. With regard to the AUDITCS the results detect that its mean is 3.511 per cent and companies' AUDITCI the average mean is 0.767 per cent, with a minimum of 2.000 and 0.250 per cent and a maximum of 6.000 and 1.000 per cent respectively. Regarding the RISKCS the outcomes notice that its mean is 3.532 per cent and companies' RISKCI the average mean is 0.572 per cent, with a maximum of 7.000 and 1.000 per cent and a minimum of 2.000 and 0.000 per cent respectively. Finally, the InterSIZE, InterEDU, InterPROF and BankSECTOR variable reveals an average mean between 5.766 per cent in the InterSIZE and 0.606 per cent in the InterEDU and 1.505 per cent in the InterPROF and 0.255 per cent in the BankSECTOR respectively.

Moreover, the control variables for the study model as shown in Table 2, reveals that the mean of firm size (FIMSI) is 6.577. The findings imply that the medium leverage (LEVGE) of the sample companies is 0.407 per cent, with a maximum of 0.959 per cent and a minimum of 0.003 per cent. Nevertheless, the descriptive analysis is considered to be a somewhat limited analysis because it does not take into account the interrelationships amongst independent variables.

Table 2

Descriptivestatistics $(\mathrm{n}=188)$

\begin{tabular}{|c|c|c|c|c|c|}
\hline Variable & Obs & Mean & Std. Dev. & Min & Max \\
\hline ROA & 188 & 0.013 & 0.045 & -0.168 & 0.140 \\
\hline BoardSIZE & 188 & 8.840 & 1.529 & 5.000 & 12.000 \\
\hline BoardNONEX & 188 & 0.464 & 0.158 & 0.000 & 0.667 \\
\hline AUDITCS & 188 & 3.511 & 0.837 & 2.000 & 6.000 \\
\hline AUDITCI & 188 & 0.767 & 0.162 & 0.250 & 1.000 \\
\hline RISKCS & 188 & 3.532 & 1.026 & 2.000 & 7.000 \\
\hline RISKCI & 188 & 0.572 & 0.242 & 0.000 & 1.000 \\
\hline InterSIZE & 188 & 5.766 & 1.188 & 0.000 & 8.000 \\
\hline InterEDU & 188 & 0.606 & 0.682 & 0.000 & 2.000 \\
\hline InterPROF & 188 & 1.505 & 0.705 & 0.000 & 3.000 \\
\hline FIMSI & 188 & 6.577 & 1.036 & 4.990 & 8.653 \\
\hline \multirow[t]{2}{*}{ LEVGE } & 188 & 0.407 & 0.374 & 0.003 & 0.959 \\
\hline & Firms & Percentage & & & \\
\hline BankSECTOR* & 47 & 25.5 & & & \\
\hline
\end{tabular}

\section{Pearson Correlation}

The Pearson Correlation analysis results representing internal audit, CG mechanisms and CP of Saudi listed companies numbering 47 from the year 2014 to 2017 are contained in Table 3. The table 3 tabulates the correlation matrix between the variables, within which the results revealed lack of significant correlations among independent variables. In the analysis of 
correlation coefficients, statistically the coefficients of correlation matrix is high with 0.9 and above indicates a serious problem of substantial collinearity (Hair, Black, Babin, \& Anderson, 2013). The correlations matrix in Tables 3 shows that there is no multicollinearity, because none of the variables correlates over 0.91 in the whole model. All variables have a correlation of less than 0.900 . Therefore, the correlation matrix test indicts that multicollinearity does not constitute an issue in the study model.

Table 3

Pearson correlation $(n=188)$

\begin{tabular}{|c|c|c|c|c|c|c|c|c|c|c|c|c|c|}
\hline${ }^{*}$ Variable & 1 & 2 & 3 & 4 & 5 & 6 & 7 & 8 & 9 & 10 & 11 & 12 & 13 \\
\hline 1. & 1.000 & & & & & & & & & & & & \\
\hline 2. & -0.018 & 1.000 & & & & & & & & & & & \\
\hline 3. & 0.033 & -0.050 & 1.000 & & & & & & & & & & \\
\hline 4. & 0.065 & 0.361 & 0.055 & 1.000 & & & & & & & & & \\
\hline 5. & 0.221 & 0.037 & 0.037 & -0.284 & 1.000 & & & & & & & & \\
\hline 6. & 0.034 & 0.252 & 0.016 & 0.330 & 0.034 & 1.000 & & & & & & & \\
\hline 7. & 0.096 & -0.132 & -0.050 & 0.084 & 0.041 & -0.106 & 1.000 & & & & & & \\
\hline 8. & -0.100 & 0.024 & 0.051 & 0.078 & -0.039 & 0.085 & 0.221 & 1.000 & & & & & \\
\hline 9. & -0.007 & 0.160 & 0.026 & 0.270 & -0.019 & 0.026 & 0.074 & 0.223 & 1.000 & & & & \\
\hline 10. & 0.104 & 0.239 & 0.014 & 0.186 & -0.035 & -0.004 & 0.096 & 0.283 & 0.505 & 1.000 & & & \\
\hline 11. & 0.065 & 0.389 & 0.128 & 0.460 & 0.020 & 0.363 & 0.228 & 0.260 & 0.537 & 0.499 & 1.000 & & \\
\hline 12. & 0.151 & 0.384 & 0.047 & 0.483 & -0.001 & 0.350 & 0.248 & 0.248 & 0.512 & 0.504 & 0.908 & 1.000 & \\
\hline 13. & -0.009 & 0.328 & -0.111 & 0.441 & 0.069 & 0.246 & 0.179 & 0.264 & 0.517 & 0.413 & 0.697 & 0.676 & 1.000 \\
\hline
\end{tabular}

Note: 1. Return On Assets ratio (ROA); 2. Board Size (BoardSIZE); 3. Board non-executive (BoardNONEX); 4. Audit Committee Size (AUDITCS); 5. Audit Committee Independence (AUDITCI); 6. Risk Committee Size (RISKCS); 7. Risk Committee Independence (RISKCI); 8. Internal audit size (InterSIZE); 9. Internal audit education (InterEDU); 10. Internal audit professional certificate (InterPROF); 11. Bank Sector (BankSECTOR); 12. Firm size (FIMSI) and 13. Leverage (LEVGE).

\section{Multiple linear regression analysis}

\section{Tests of heterokedasticity and autocorrelation}

In regression analysis with cross-section data, one of the general violations is the presence of heteroscedasticity (Hair, Black, Babin\& Anderson, 2013). This issue results in greater $\mathrm{t}$ and $\mathrm{f}$ values, with the null hypotheses having a high tendency to be rejected, where otherwise they will be accepted. This reveals that the dependent variable variation is not consistently interpreted by any of the independent variables, restricting how the regressor's impacts are interpreted. In this study, two tests of heteroscedasticity were used for the detection of the issue namely, Breusch and Pagan (1979) and Cook and Weisberg's (1983) tests. The tests for the entire models generally indicate a ranking of heteroscedasticity wherein the 
differences do not persist. As a conseue3nce, to address heteroscedasticity, the present study used robust standard errors in the analyses as recommended by Eicker (1963), Huber (1967) and White (1980).

As for the panel dataset, it encapsulates observations that have duplicated and placed on similar cross-sections, wherein it is evident that the firm-year observations contain autocorrelations (Wooldridge, 2010), calling for the need to run the autocorrelation test to identify potential issues in first-order time series autocorrelation. On the basis of the test results, no autocorrelation was found in the study models.

\section{Cross-sectional time-series fgls regression}

Owing to the data nature focused on a distinct set of industry, where the inference is confined to specific behavior, FGLS regression was found to be suitable to be used in this study. Fixed effects model can be viewed based on the diagnostic examination test results (Baltagi, 2008). Moreover, the study conducted Hausman specification test, where the firm effects were justified to be employed over the random effects (prob< chi2 less than .05), which means that null hypothesis is rejected, with the evidence of insignificant differences throughout firms. Consequently, fixed effects regression was opted for as the second option as suggested by Gujarati (2015). Also, owing to the detected autocorrelation, a cross-sectional timeseries FGLS regression (panels, heteroskedastic) corr (independent) (xtgls) was preferred over the fixed effects regression a suggested by Quinonez, Saenz and Solorzano (2018).

The empirical findings showed that non-executive board, audit committee size, audit committee independence, internal auditor professional certification and firms size related to $\mathrm{CP}$, while board size, internal audit size, internal education and leverage had a negative and significant relationship with CP as provided in the table 4.

Table 4

Cross-sectional time-series FGLS regression ( $\mathrm{n}=188)$

\begin{tabular}{|c|c|c|}
\hline Variable & Predicted Sign & Model ROA \\
\hline Board Size & - & $\begin{array}{l}-0.003 * * \\
(-2.60)\end{array}$ \\
\hline Board non-executive & + & $\begin{array}{l}0.019 * \\
(2.23)\end{array}$ \\
\hline Audit Committee Size & + & $\begin{array}{l}0.007 * * * \\
(3.54)\end{array}$ \\
\hline Audit Committee Independence & + & $\begin{array}{l}0.046 * * * \\
(4.82)\end{array}$ \\
\hline Risk Committee Size & + & $\begin{array}{l}0.0000 \\
(0.03)\end{array}$ \\
\hline Risk Committee Independence & + & $\begin{array}{l}0.006 \\
(0.75)\end{array}$ \\
\hline Internal audit size & + & $\begin{array}{l}-0.002 * \\
(-1.89)\end{array}$ \\
\hline Internal audit education & + & $\begin{array}{l}-0.003 * \\
(-1.69)\end{array}$ \\
\hline
\end{tabular}




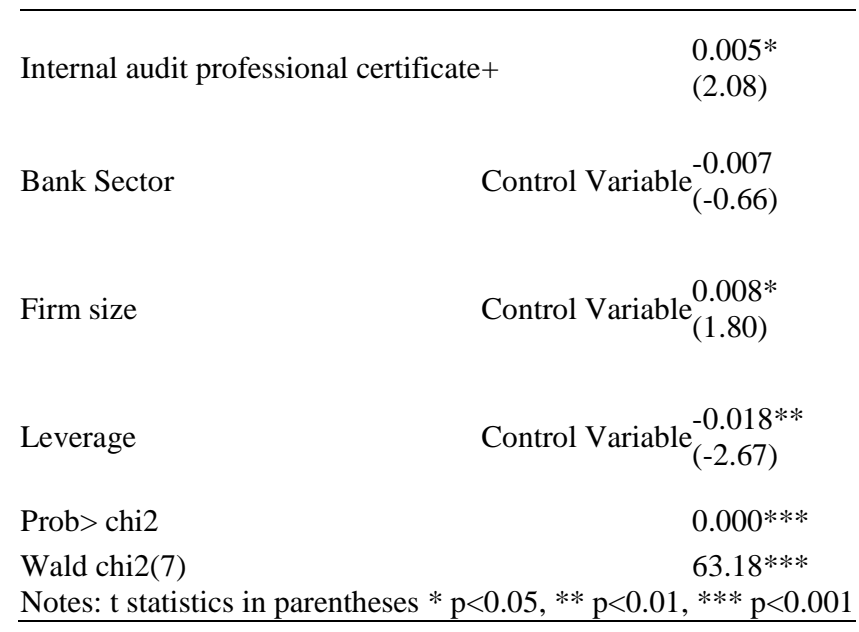

\section{Hierarchical multiple linear regression}

Regression results on the moderating effects of internal audit

According to the obtained results, Prob> chi2 is lower than 5\% and no evidence of heterokedasticity and autocorrelation was detected. The level to which the variables had multicollinearity, heteroskedasticity and autocorrelation presence was determined through the use of regression analysis. The regression analysis results are tabulated in Table 5 using the FGLS method.

Table 5

Regression results on the moderating effects of internal audit

\begin{tabular}{llll}
\hline Variable & Expected & Model 1 & Model 2 \\
BoardSIZE & - & $-0.003 * *$ & $-0.024 * *$ \\
& & $(-2.60)$ & $(-2.31)$ \\
BoardNONEX & + & $0.019 *$ & 0.022 \\
& & $(2.23)$ & $(1.42)$ \\
AUDITCS & + & $0.007 * * *$ & $0.009 * * *$ \\
& & $(3.54)$ & $(2.73)$ \\
AUDITCI & + & $0.046 * * *$ & $0.07 * * *$ \\
& & $(4.82)$ & $(4.19)$ \\
RISKCS & + & 0.000 & -0.001 \\
& & $(0.03)$ & $(-0.34)$ \\
RISKCI & + & 0.006 & -0.004 \\
& & $(0.75)$ & $(-0.38)$ \\
InterSIZE & & $-0.002 *$ & $-0.03 * *$ \\
& + & $(-1.89)$ & $(-2.53)$ \\
\hline
\end{tabular}




\begin{tabular}{|c|c|c|c|}
\hline InterEDU & + & $\begin{array}{l}-0.003 * \\
(-1.69)\end{array}$ & $\begin{array}{l}0.014 \\
(0.33)\end{array}$ \\
\hline InterPROF & + & $\begin{array}{l}0.005^{*} \\
(2.08)\end{array}$ & $\begin{array}{l}-0.012 \\
(-0.59)\end{array}$ \\
\hline BoardSIZE_ E & $-/+$ & - & $\begin{array}{l}0.003 * * \\
(2.25)\end{array}$ \\
\hline BoardSIZE_ U & $-/+$ & - & $\begin{array}{l}-0.002 \\
(-0.36)\end{array}$ \\
\hline BoardSIZE_ F & $-/+$ & - & $\begin{array}{l}0.002 \\
(0.79)\end{array}$ \\
\hline BankSECTOR & & $\begin{array}{l}-0.00691 \\
(-0.66)\end{array}$ & $\begin{array}{l}-0.02 \\
(-1.60)\end{array}$ \\
\hline FIMSI & & $\begin{array}{l}0.008^{*} \\
(1.80)\end{array}$ & $\begin{array}{l}0.009 * \\
(1.94)\end{array}$ \\
\hline LEVGE & & $\begin{array}{l}-0.018 * * \\
(-2.67)\end{array}$ & $\begin{array}{l}-0.000 \\
(-0.00)\end{array}$ \\
\hline $\begin{array}{l}\text { Prob> chi2 } \\
\text { Wald chi2(7) }\end{array}$ & & & $\begin{array}{l}0.014 * * \\
29.44 * * *\end{array}$ \\
\hline
\end{tabular}

Notes: $\mathrm{t}$ statistics in parentheses $* \mathrm{p}<0.05, * * \mathrm{p}<0.01, * * * \mathrm{p}<0.001$

According to Wooldridge (2010), the FGLS is a useful method to maintain control of heterokedasticity and autocorrelation. On the basis of the above table 5, the moderating effect results of internal audit on the CG mechanisms-CP relationship among Saudi listed firms indicated that internal audit size positively moderated the board size-CP relationship among Saudi listed firms, while internal audit education and internal audit professional certificate had no moderating effect on the board size-CP relationship as showed in the table 5.

\section{Discussion of results}

The cross-sectional time series feasible general least squares (FGLS) regression results showed support for the five hypotheses, while the remaining four were rejected. One moderating hypothesis was supported while the remaining two were rejected. Discussion of the direct and moderating results are detailed in this sub-section.

Aligned with the assumptions provided by the agency theory, there was a significant negative relationship between board size and CP, which reveals support for hypothesis H1. The result also showed that board size has a negative relationship with CP. Prior studies findings that are consistent with the result between board size and performance in countries are tabulated in Table 4. From the table 4, it is evident that several studies supported this result including AlMalkawi (2018), Fanta et al. (2013), Mersni and Othman (2016), Yermack (1996) and Lee and Chen (2011). In this regard, the significant negative effect of the size of the board on the performance of organizations, as represented by ROA, can be related to the potential of CEO domination over the board, which leads to information asymmetry that could confine the strength of the board's oversight responsibilities as argued by Hasnah (2009).

With regards to the board independence-CP relationship, the findings of this study support a positive relationship (see Table 4). This is aligned with prior studies (Al-Sahafi et al., 2015; Bhattrai, 2017; Bace, 2017), which revealed that 
board independence, measured by the independent members upon total members has direct link to performance. More importantly, the global code and Saudi CG code are both clear on this matter in that it made it compulsory for the board to consist of majority independent directors considering its primary concern is to oversee and control the activities of the firm and to minimize management opportunistic intentions and expropriation of resources. This indicates support for hypothesis H2. Also, this positive significant relationship between board independence and CP can be linked to the non-executive members' power to design and develop the business strategic plans.

Regarding the audit committee size-corporate performance relationship, the result supports the proposed hypothesis (see Table 4). The result is also consistent with the statement of the Blue-Ribbon Committee (1999) regarding the importance of improving corporate audit committee effectiveness through the setting up of the Cadbury Commission, and through ensuring that committees should have at least three members that are NEDs. The same holds true for the Saudi CG code that stresses on the oversight role of audit committee when it comes to internal control framework and its need to review the financial reporting process to enhance the performance of the firm. This result supports hypothesis $\mathrm{H} 3$ of the study and it can be related to the audit committee importance among developed countries and the role of specific board practices elements in such countries, particularly in the Saudi listed firms. In Table 4 it is also evident that the results support a positive and significant relationship between audit committee independence and ROA.

The above finding reveals that audit committee independence is linked to a higher level of performance, which is consistent with both the global code and Saudi CG code, as well as, prior findings. For instance, Buallay (2018) supported the key role of audit committee independence on the adherence of CG auditing practices to a standardized financial report. On this basis, the fourth hypothesis (H4) is supported.

In addition to the above, the positive relationship between audit committee independence and $\mathrm{CP}$ can also be related to the assumptions of the agency theory and resource dependence theory, which states that autonomous independent reviewers, who have the leeway of making informed decisions, errors detection and the like, can easily facilitate effective work and provide unbiased judgment.

Moreover, the underpinning theories (agency theory and resource dependence theory) argue that the relationship between risk committee size and corporate performance (ROA) is significant but an insignificant relationship was found between the two, supporting the accounting-based measurement outcome, but rejecting hypothesis H5. This insignificant result may be linked to the risk committees that are often understated in their role in Saudi firms when compared to the committee on its own. This means some board practices that are important to the Western businesses and firms are not so much in the Saudi firms. Also, the Saudi CG code does not lay stress on the executive committee's role in enhancing the performance of the firm.

It has always been argued by the theories (agency theory and resource dependence theory) that a positive relationship exists between the independence of risk committee and ROA but in this study's results, an insignificant relationship was found as evidenced in Table 4, which means H6 is rejected. The result may be because of the low level of presence of risk committee independence on the board, which falls short of being sufficient enough for the committee to effectively conduct their monitoring role. It is important to ensure that independent committee members are experts in the field to be able to contribute value to the firm.

The first significant internal audit characteristics is the internal audit size and it is assumed to enhance the companies' performance, and as such, this study proposes the positive relationship between ROA and internal audit size. Table 4 however shows a contrasting relationship, where a significant negative relationship was found between internal audit size and ROA, which means hypothesis H7 is rejected. This result may explain the inability of the Saudi listed firms of motivating creativity, what with the processes under strict control of the board of directors, which makes the internal 
audit as a follower rather than a leader when it comes to oversight responsibilities. This calls for the regulators of capital market to lay down the responsibilities of the CEO towards enhancing the performance of the company.

In hypothesis H8, it was proposed that a positive relationship exists between internal audit education and firm performance, where the higher the experience and knowledge of internal audit, the higher will be the level of performance (i.e., resource dependence theory and agency theory). But contrary to the hypothesized relationship, Table 4 shows an insignificant relationship that rejects hypothesis H8. This may be linked to the erroneous belief that internal audit education reflects enhanced $\mathrm{CP}$ as on the basis of the sample characteristics, majority of the study sample had low education qualifications.

This study also proposed, in hypothesis H9, that a positive relationship exists between professional certification of internal audit and firm strategy, policy and decision making and the results support such hypothesis (H9). Such significant positive relationship between the two variables may be attributed to the recruitment policy ensuring that certified and qualified individuals are employed.

As for the proposed moderating effects in this study, with the internal audit mechanisms (size, education and professional certification) as the moderating variables that effect board size and performance, the results indicated support for the first moderating hypothesis (H10). Specifically, internal audit size has a moderating role on the board size and performance relationship and such moderating effect may be related to the audit members' number on the audit committee that is sufficient to ensure their effectiveness. In relation to this, the internal audit board contributes to the committee by providing feedback that can be utilized to meet the aims and objectives and to eventually enhance the profitability and value of the firm. Lastly, the moderating effects of internal audit education and professional certification was proposed between

board size and performance but the results stated otherwise and thus, hypothesis H11 and H12 is rejected. This may be because of the board members inefficient role, lack of qualification, experience and knowledge, which leads to ineffective internal audit process.

\section{Conclusions}

The significance of effective and good CG has been increasingly focused on in both public and regulatory fields, with a crucial CG component being its internal audit function. Meanwhile, public concern of the fraud level within organizations has been increasing, necessitating the examination of the internal audit function of organizations to determine fraud. Accordingly, this study is a pioneering one in examining the moderating effect of internal audit on the CG mechanismsperformance relationship.

Additionally, this study investigated the direct relationships between characteristics of CG, characteristics of internal audit and CP in the context of Saudi listed firms in a four-year span (2014-2017). The study employed FGLS regression to examine the direct relationship between internal audit mechanisms and CG, with $\mathrm{CP}$. Based on the empirical findings, non-executive board members, audit committee size, audit committee independence, internal audit professional certification and firm size had a significant relationship with CP. Internal audit was found to positively moderate the board size-CP relationship among Saudi listed firms. However, significantly negative relationships were found between board size, internal audit size, internal audit education and leverage, with CP.

This study is one of its kind in that it is the first to examine the moderating effects of internal audit mechanisms on the relationship between CG mechanisms and CP in Saudi Arabia, as a developing nation. This study also contributes through its justification of the underpinning theories (agency theory and resource dependence theory) in providing insights into CP in the Saudi context. 
This study has its own limitations, with the first being that its scope is limited to examining the moderating effects of internal audit on the relationship between CG mechanisms and CP among Saudi listed financial firms in Saudi Arabia. In the future, authors can embark on examining the same variables but in the GCC context. This study is also limited in confining its moderating effects testing to internal audit mechanisms of size, education and professional certification and in this regard, future works can be dedicated to examining other moderating variables like board characteristics, audit committee characteristics, risk committee characteristics, remuneration committee characteristics, among others on the board size-CP association. The study is also limited in its use of ROA as a proxy for CP. Future studies can use alternative accounting measures and market measures that can furnish a more complete insight in to firm performance. In this study, three internal audit mechanisms were examined - and as such, in future studies, other additional mechanisms can be included for examination. Finally, the financial firms which comprise the study sample are listed in Saudi stock market and with this in mind, future studies are recommended to include non-financial listed firms as well.

\section{Acknowledgment}

The authors would like to extend their appreciation to the Deanship of Scientific Research at Jouf University for funding this work through General Research Project under grant number (G.R.P- 701 -39).

\section{References}

Abdallah, A. A.-N., \& Ismail, A. K. (2017). Corporate Governance Practices, Ownership Structure, and Corporate Performance in the GCC Countries. Journal of International Financial Markets, Institutions and Money, 46, 981115.

Abdullah, S. N. (2004). Board composition, CEO duality and performance among Malaysian listed companies. Corporate Governance, 4(4), 47-61.

Aburime, U. T. (2009). Impact of Political Affiliation on Bank Profitability in Nigeria. Journal of Accounting, Economics, Finance and Banking Research, 4(4), 61-75.

Ahmed, E., \&Hamdan, A. (2015). The impact of corporate governance on firm performance: Evidence from Bahrain Bourse. International Management Review, 11(2), 21.

Alajlan, W. (2015). Ownership patterns and the Saudi market. Corporate Governance, 9, 161-186.

Albassam, W. M. (2014). Corporate governance, voluntary disclosure and financial performance: An empirical analysis of Saudi listed firms using a mixed-methods research design. PhD Thesis. University of Glasgow. UK.

Al-Bassam, W. M., Ntim, C. G., Opong, K. K., \& Downs, Y. (2018). Corporate boards and ownership structure as antecedents of corporate governance disclosure in Saudi Arabian publicly listed corporations. Business \& Society, 57(2), 335-377.

Al-Ghamdi, M., \& Rhodes, M. (2015). Family Ownership, Corporate Governance and Performance: Evidence from Saudi Arabia. International Journal of Economics and Finance, 7(2), 78-89.

Al-Hadi, A., Hasan, M. M., \& Habib, A. (2016). Risk committee, firm life cycle, and market risk disclosures. Corporate Governance: An International Review, 24(2), 145-170.

Al-Janadi, Y., Rahman, R. A., \&Alazzani, A. (2016). Does government ownership affect corporate governance and corporate disclosure? Managerial Auditing Journal, 31(8/9), 871-890.

Aljifri, K., \&Moustafa, M. (2007). The impact of corporate governance mechanisms on the performance of UAE firms: an empirical analysis. Journal of Economic and Administrative Sciences, 23(2), 71-93. 
Al-Malkawi, H. A. N., \& Pillai, R. (2018). Analyzing financial performance by integrating conventional governance mechanisms into the GCC Islamic banking framework. ManagerialFinance, 44(5), 604-623.

Al-Matari, E. M., Al-Swidi, A. K., \&Fadzil, F. H. B. (2014). The Measurements of Firm Performance's Dimensions. Asian Journal of Finance \& Accounting, 6(1), 1-24.

Al-Matari, E. M., Al-Swidi, A. K., Faudziah, H. B., Al-Matari, Y. A. (2012). The Impact of board characteristics on Firm Performance: Evidence from Nonfinancial Listed Companies in Kuwaiti Stock Exchange. International Journal of Accounting and Financial Reporting, 2(2), 310-332.

Al-Matari, Y. A., Al-Swidi, A. K., Fadzil, F. H. B. F. H., \& Al-Matari, E. M. (2012). Board of Directors, Audit Committee Characteristics and the Performance of Saudi Arabia Listed Companies. International Review of Management and Marketing, 2(4), 241-251.

Al-Nodel, A., \&Hussainey, K. (2010). Corporate governance and financing decisions by Saudi companies. Journal of Modern Accounting and Auditing, 6(8), 1-14.

Al-Obaidan, A. M. (2008). Market structure concentration and performance in the commercial banking industry of emerging markets. European Journal of Economics, Finance and Administrative Sciences, 12(1), 104-114.

Alotaibi, M. (2015). The Importance of Corporate Governance in Saudi Arabia Economy. Journal of WEI Business and Economics, 4(1), 14-27.

Alsaeed, K. (2006). The association between firm-specific characteristics and disclosure: The case of Saudi Arabia. Managerial Auditing Journal, 21(5), 476-496.

Al-Sahafi, A., Rodrigs, M., \& Barnes, L. (2015). Does Corporate Governance Affect Financial Performance InThe Banking Sector? Evidence from Saudi Arabia, International Journal of Economics, Commerce and Management, III (3), 126.

Al-Shetwi, M., Ramadili, S. M., Chowdury, T. H. S., \&Sori, Z. M. (2011). Impact of internal audit function (IAF) on financial reporting quality (FRQ): Evidence from Saudi Arabia. African Journal of Business Management, 5(27), 11189-11198.

Alzeban, A. (2018). The association between internal audit department characteristics and IFRS compliance. Asian Review of Accounting, 26(3), 336-358.

Andres, P. D., \&Vallelado, E )2008(. Corporate governance in banking: The role of the board of directors. Journal of Banking and Finance, 32, 2570-2580.

Baltagi, B. (2008). Econometric analysis of panel data (4th ed.). New York: John Wiley \& Sons.

Bace, E. (2017). Corporate governance and performance of Saudi banks: 2010-2015. In: 1st International Conference on Advanced Research (ICAR-2017), 25-26 Jan 2017, The Domain Hotel, Manama, Kingdom of Bahrain.

Beasley, M. S., Clune, R., \&Hermanson, D. (2006). The impact of enterprise risk management on the internal audit function: Digital Commons@ Kennesaw State University Kennesaw, GA.

Berle, A., \& Means, G. (1932). The modern corporation and private property. New York, NY: Macmillan.

Bhattrai, H. (2017). Effect of corporate governance on financial performance of bank in Nepal. ZENITH International Journal of Multidisciplinary Research, 7(3), 97-110.

Blue Ribbon Committee on Improving the Effectiveness of Corporate Audit Committees. (1999). Report and recommendations of the Blue Ribbon Committee on improving the effectiveness of corporate audit committees. The Business Lawyer, 1067-1095.

Breusch, T. S., \& Pagan, A. R. (1979). A simple test for heteroscedasticity and random coefficient variation. Econometrica: Journal of the Econometric Society, 1287-1294. 
Buallay, A. (2018). Audit committee characteristics: an empirical investigation of the contribution to intellectual capital efficiency. Measuring Business Excellence.

Buallay, A., Hamdan, A., \&Zureigat, Q. (2017). Corporate governance and firm performance: evidence from Saudi Arabia. Australasian Accounting, Business and Finance Journal, 11(1), 78-98.

Celenza, D., \& Rossi, F. (2014). Intellectual capital and performance of listed companies: empirical evidence from Italy. Measuring Business Excellence, 18(1), 22-35.

Clikeman, P. M. (2003). Where auditors fear to tread: internal auditors should be proactive in educating companies on the perils of earnings management and in searching for signs of its use. Internal Auditor, 75-0.

Coram, P., Ferguson, C., \&Moroney, R. (2008). Internal audit, alternative internal audit structures and the level of misappropriation of assets fraud. Accounting and Finance, 48, 543-559.

D’Aveni, R. A. (1990). Top managerial prestige and organizational bankruptcy, Organization Science, 1(2), 121-2.

Dittenhofer, M. (2001). Internal audit effectiveness: an expansion of present methods. Managerial Auditing Journal, 16(8),443-50.

Eicker, F. (1963). Asymptotic normality and consistency of the least squares estimators for families of linear regressions. The Annals of Mathematical Statistics, 447-456.

Eighme, J., Cashell, J. (2002). Internal auditors' roles in overcoming the financial reporting crisis. International Auditing, 17, 3-10.

Ellul, A., \&Yerramilli, V. (2011). Stronger Risk Controls, Lower Risk: Evidence from US Bank Holding Companies. Working Paper, Indiana University.

Fallatah, Y., \& Dickins, D. (2012). Corporate governance and firm performance and value in Saudi Arabia. African Journal of Business Management, 6(36), 10025-10034.

Fama, E., \& Jensen, M. (1983).Agency problems and residual claims. The Journal of Law and Economics,26(2), $327-349$.

Fanta, A. B., Kemal, K. S., \& Waka, Y. K. (2013). Corporate governance and impact on bank performance. Journal of Finance and Accounting, 1(1), 19-26.

Field, L., Lowry, M., \&Mkrtchyan, A. (2013). Are busy boards detrimental?. Journal of Financial Economics, 109(1), 6382.

García-Meca, E., \& Sánchez-Ballesta, J. P. (2011). Firm value and ownership structure in the Spanish capital market. Journal of Corporate Governance, 11(1), 41-53.

Mihret, D. G., \&Yismaw, A. W. (2007). Internal audit effectiveness: an Ethiopian public sector case study. Managerial auditing journal, 22(5), 470-484.

Ghabayen, M. (2012). Board characteristics and firm performance: Case of Saudi Arabia. International Journal of Accounting and Financial Reporting, 2(2), 168-200.

Goodwin, J. (2003). The relationship between the audit committee and the internal audit function: Evidence from Australia and New Zealand. International Journal of Auditing 7(3), 263-278.

Goodwin, J., Yeo, T. Y. (2001). Two Factors Affecting Internal Audit Independence and Objectivity: Evidence from Singapore. International Journal of Auditing 5(2), 107-125.

Gramling, A. A., \& Myers, P. M. (2006). Internal auditing's role in ERM: as organizations lay their enterprise risk groundwork, many auditors are taking on management's oversight responsibilities, new research finds. Internal Auditor, 63(2), 52-58.

Gramling, A. A., Maletta, M. J., Schneider, A., \& Church, B. K. (2004). The role of the internal audit function in corporate governance: A synthesis of the extant internal auditing literature and directions for future research. Journal of Accounting literature, 23, 194. 
Gujarati, P. (2015). Basic Econometrics (5th ed.). New York: McGraw-Hill Education.

Hair, J. F., Black, W. C., Babin, B. J., \& Anderson, R. E. (2013). Multivariate Data Analysis (7th ed.). New Jersey: Pearson Education, Limited.

Hala, N. (2003), Sherron Watkins - If capitalists were angels, Internal Auditor 60(11), 38-43.

Hamdan, A. M., \&Mushtaha, S. (2011). The relationship between audit committee characteristics and type of auditor's report: an empirical study on the public shareholding industrial companies listed at Amman Bourse. The Arab Journal of Accounting, 14(1), 109-163.

Hamdan, A. M., Sarea, A. M., \&Reyad, S. M. R. (2013). The impact of audit committee characteristics on the performance: evidence from Jordan. International Management Review, 9(1), 32.

Haniffa, R., \&Hudaib, M. (2006). Corporate governance structure and performance of Malaysian listed companies. Journal of Business Finance \& Accounting, 33(7) \& (8), 1034-1062.

Hasnah, K. (2009). The impact of corporate governance and board performance on the performance of public listed companies in Malaysia. Ph.D Dissertation, University Sains Malaysia.

Hillman, A., \& Dalziel, T. (2003). Boards of directors and firm performance: Integrating agency and resource dependence perspectives. Academy of Management Review, 28(3), 383-396.

Huber, P. J. (1967, June). The behavior of maximum likelihood estimates under nonstandard conditions. In Proceedings of the fifth Berkeley symposium on mathematical statistics and probability, 1(1),221-233).

Hutchinson, M. R., \& Zain, M. M. (2009). Internal audit quality, audit committee independence, growth opportunities and firm performance. Corporate Ownership and Control, 7(2), 50-63.

IIARF, I. (2003). Research Foundation. Internal Audit Reporting Relationships: Serving Two Masters.

Inkinen, H. (2015). Review of empirical research on intellectual capital and firm performance. Journal of Intellectual capital, 16(3), 518-565.

Institute of Internal Auditors, (2004). Practice Advisory 2130-1: Role of the Internal Audit Activity and Internal Auditor in the Ethical Culture of an Organization (IIA, Altamonte Springs, FL).

Jensen, M. \&Meckling, W. H. (1976). Theory of the firm: managerial behavior, agency costs, and ownership structure. Journal of Financial Economics, 3, 305-360.

Jensen, M. (1993). The modern industrial revolution, exit and the failure of internal control systems. Journal of Finance, 48, 831-880.

John, K., \&Senbet, L. W. (1998). Corporate governance and board effectiveness. Journal of Banking \& Finance, 22(4), 371 403.

Khamis, A., Hussein, A., \&Elmogy, A. (2015). Multi-robot task allocation: A review of the state-of-the-art. In Cooperative Robots and Sensor Networks 2015 (pp. 31-51). Springer, Cham.

Kantudu, A. S., \&Samaila, I. A. (2015). Board Characteristics, Independent Audit Committee and Financial Reporting Quality of Oil Marketing Firms: Evidence from Nigeria. Journal of Finance, Accounting \& Management, 6(2).

Lee, L. - D. \& Chen, H.-J. (2011). Corporate governance and firm value as determinants of CEO compensation in Taiwan: 2SLS for panel data model. Management Research Review, 34(3), 252-265

Lee, S., \& Park, S. Y. (2010). Financial impacts of socially responsible activities on airline companies. Journal of Hospitality \& Tourism Research, 34(2), 185-203.

Lipton, M., \&Lorsch, J. (1992). Modest proposal for improved corporate governance. Business Lawyer,12(3), 48-9.

Ljubisavljevic, S., \&Jovanovi , D. ( 2011). Empirical research on the internal audit position of companies in Serbia. Economic Annals, 56(191), 123-141. 
Mersni, H., \& Othman, H. B. (2016). The impact of corporate governance mechanisms on earnings management in Islamic banks in the Middle East region. Journal of Islamic Accounting and Business Research, 7(4), 318-348.

Mgammal, M. H. (2017). The effect of ownership structure on voluntary disclosure: Evidence from Saudi Arabia. Journal of Advanced Management Science,5(2), 138-151.

Mongiardino, A., \& Plath, C. (2010). Risk governance at large banks: Have any lessons been learned?.Journal of Risk Management in Financial Institutions, 3(2), 116-123.

Nuryanah, S., \& Islam, S. M. N. (2011). Corporate governance and performance: Evidence from an emerging market. Malaysian Accounting Review, 10(1), 17-42.

Patro, S., Lehn, K., \& Zhao, M. (2003). Determinants of the size and structure of corporate boards: 1935-2000.Financial Management, 38, 1-57.

Peng, M. W., Li, Y., Xie, E., \& Su, Z. (2010). CEO duality, organizational black and firm performance in China. Asia Pacific Journal of Management, 27, 611-624.

Pissaris, S., Jeffus, W., \& Gleason, K. C. (2010). The joint impact of executive pay disparity and corporate governance on corporate performance. Journal of Managerial, 22(3), 306-329.

Prawitt, D., Smith, J., \& Wood, D. (2009). Internal Audit Quality and Earnings Management. The Accounting Review, 84, 1255-1280.

Quinonez, P., Saenz, J., \&Solorzano, J. (2018). Does foreign direct investment reduce poverty? The case of Latin America in the twenty-first century. BEH - Business and Economic Horizons, 14(3), 488-500.

Ramly, Z., \&Nordin, N. D. H. M. (2018). Sharia Supervision Board, Board Independence, Risk Committee and Risk-taking of Islamic Banks in Malaysia. International Journal of Economics and Financial Issues, 8(4), 290-300.

Sawyer, L. B. (1995). An internal; audit philosophy”, Internal Auditor, August, 46-55. Sciences, 23 (2), 71-93.

Shah, S., \& Jan, R. (2014). Analysis of Financial Performance of Private Banks in Pakistan, Social and Behavioral Sciences 109, 1021-1025.

Shaver, D. (2005). Characteristics of corporate boards in single-industry and conglomerate media companies. International Journal of Media Management, 7(3\&4), 112-120.

Shleifer, A., \&Vishny, R. W. (1986).Large shareholders and corporate control. Journal of Political Economy,94(3), 461488.

Smith, A. (1776). An Inquiry into the nature and causes of the wealth of nations, The Clarendon press, Oxford.

Spraakman, G. (1997). Transaction cost economics: a theory of internal audit. Managerial Auditing Journal,7, 323-30.

Srinivas, V., Goradia, U., Therattil, L.F., \& Dillon, D. (2015), Bank Board Risk Governance: Driving Performance through Enhanced Risk Oversight. The United States of America: Deloitte University Press.

Subramaniam, N., McManus, L., \& Zhang, J. (2009). Corporate Governance, Firm Characteristics and Risk Management Committee Formation in Australian Companies. Managerial Auditing Journal, 24(4), 316-339.

Sultana, N., Singh, H. \& Van der Zahn, J.L.W.M. (2015). Audit committee characteristics and audit report lag. International Journal of Auditing, 19(2): 72-87.

Uadiale, O. M. (2012). Earnings management and corporate governance in Nigeria. Research Journal of Finance and Accounting, 3(3), 1-10.

Wahla, K. U. R., Shah, S. Z. A., \& Hussain, Z. (2012). Impact of ownership structure on firm performance evidence from non-financial listed companies at Karachi stock exchange. International Research Journal of Finance and Economics, 84, 6-13.

Walsh, J. P., \& Seward, J. K. (1990). On the efficiency of internal and external corporate control mechanisms. Academy of Management Review, 15 (3), 421-458. 
White, H. (1980). A heteroskedasticity-consistent covariance matrix estimator and a direct test for heteroskedasticity. Econometrica: Journal of the Econometric Society, 817-838.

Wooldridge, J. M. (2010). Econometric Analysis of Cross Section and Panel Data. Cambridge, MA: MIT Press.

Xiangdong, W. (1997). Development trends and future prospects of internal auditing”, Managerial Auditing Journal, 12(4/5), 200-4.

Yermack, D. (1996). Higher market valuation of companies with a small board of directors. Journal of Financial Economics, $40(2), 185-211$.

Zaman, R., Arslan, M., \& Siddiqui, M. A. (2014). Corporate governance and firm performance: the role of transparency \& disclosure in banking sector of Pakistan. International Letters of Social and Humanistic Sciences, 43, 152-166.

Zain, M. N., Subramaniam, N. \& Goodwin-Stewart, J. (2006). Internal Auditors Assessment of their Contribution to Financial Statement Audits: The Relation with Audit Committee and Internal Audit Characteristics, International Journal of Auditing, 10(1), 1-18.

Ziegenfus, D. E. (2000). Developing an internal auditing department balanced scorecard, Managerial Auditing Journal, 15(1/2), 12-19. 